quinine with meals, and a tiny dose of potassium iodide and sodium bicarbonate at bedtime, dry cupping in extreme pain in sciatica or lumbago. Of course, care in minor matters is presumed, such as After thee or four weeks of hydrotherapeutics, "Member's" instincts will lead him to golf or cycling and to a square meal.

DR. B. ADDY (Birkdale) writes: I suffered for years in a similar way. In my opinion the muscles become stiff and painful from their quiescent state during the night. For medicinal treatment I found potassium
iodide with ammoniated tincture of guaiacum 3 ss taken regularly most efficacious. I order guaiacum very freely, and rarely find it fail to eficacious. give relief in rheumatic and gouty affections. My sciatica was benefited by the hot douches at Bath whilst immersed in the bath applied for 15 minutes along the sciatic nerve. As to diet, avoid animal food as
much as possible; in fact, Dr. Haig's views on diet meet with my much as possible; in fact, Dr. Haig's views on diet meet
strongest personal approval, and I have largely followed them.

Civil or Military?

NavY.-In answer to our correspondent, who wants advice as to whether plic services-for a limited time before beginning private practice, we reply : He is not too old at 24 to enter, career; but we have grave doubts if, as he proposes, twelve years' service in the navy or army, and retirement by gratuity, is likely to prove a good introduction to private practice. He would be close on 40 before a could begin, and at that age a practitioner who begins early has either made or marred his civil career. We would rather advise him to choose quickly and definitively, as a life career. either one of the public services or civil practice. The system which he proposes was tried in the army about twenty years ago, among the so-called "thousand pounders," and did not prove a success.

NOTES, LETTERS, Ete.

First Aid Lectures: Medical Sweating.

政 of the BnTrish Mold asking for thedeal men to give courses of six lectures on First Aid and Nursing at $\mathcal{E}_{3} 3$ 3s. a course. Hitherto the recognised fee for these lecstances in which the medical man has had to lecture for a merely nominal fee or none at all, but those have been owing to purely local circumstances, such as the social condition of the class with its consequent inability to raise the orthodox amount

Poverty cannot be the reason assigned by the London School Board for attempting to bring down the price of these lectures. It is medical sweating, pure and simple, and of a gross form, and I sincerely hope that no one who has been accustomed to lecture will condescend to work for the London School Board for the fee advertised.

Rheumatic heart Disease in Children : A Correction

Dr. F. John Poyn'on, (St. Mary's Hospital) writes: I should like to correct a slight misstatement in the report of the discussion on Rheumatic Heart Disease in Children, introduced bo Dr. Lees, at the Association meeting in the BRITISH MEDICAL JOURNAL of October 15th, I have apparently cominented upou the discovery of an aërobic bacillus in rheumatic fever by Dr. Pierre Aclialene. It should be an anaërobic bacillus, and the name Achalme.

\section{A Correction.}

DR. H. Geary Dyer, of Ringwood. Hants, to whom some remarks were attributed in the discussion on the Treatment of Spinal Curvature in the Section of Diseases of Children, published in the BRITISH MEDICAL JOURNAL of October x 5 th, page rr29, writes to say that " greatly, to his disappointment he was not within 500 miles of Edinburgh town", at the time of the annual meeting. We take this opportunity of pointing out that mistakes of this kind, and a great deal of inconvenience to all concerned, would be prevented if the speakers in discussions at the annual
meetings would sign their names in fulr to their notes of their remarks.

\section{SAWDUST AS a SURGICAL DRESSING.}

Mr. ERNeST A. T. STEELE, M.R.C.S. (Southend-on-Sea) writes: In the BRITISH MEDICAL JOURNAL of September 24 th, Dr. Neve, of the Mission Hospital, Kashmir, describes a method of using sawdust as a surgical dressing. This method is not new, for: I saw it used by Mr. Rushton Parker at the Royal Infirmary, Liverpool, at least ten or eleven years ago, and I have since frequently used sawdust prepared in the way nant disease and septic suppurating wounds among the poor.

\section{"Cleanliness DURING 'THE MONTHLy Pertod"}

MR. W. CECIL SHARPE M B. Edin (Matlock) writes: Although not a lady doctor, I can reassure Dr: Stoney as to the harmlessness of ordinary has been my routine practice for some time to prescribe sponging or hip baths of a few minutes' duration at a temperature of $85^{\circ}$ to $95^{\circ} \mathrm{F}$. nipht and morning daily during the period, the heat of the bath to be gradually reduced to $60^{\circ}$ as soon as the flow has ceased. Many ladies have expressed to me the sense of relief and comfort experienced by this means. In robust and healthy subjects a general bath may be per mitted if taken above, $70^{\circ}$ and below $90^{\circ}$, but these should be advised mitted if taken above, $70^{\circ}$ and below $90^{\circ}$, but these should be advised well as a rule. I have known even a Turkish bath to be taken without well as a rule. I have known even a Turkish bath to be taken without mended. The use of the hot deep sitz bath for the relief of dysmenorrhoea is of course well known, and I can only add my testimony to its ralue in numerous cases. vaginal douches may be used instead, vat are not so generally efficacious. Tepid vaginal douches are harmbut are not so generally efficacious. Tepid vaginal douche
less, though perhaps superfluous if the sponge bath is used.
LETTERS, COMMUNIOATIONS, ETO., have been received from

A Mr. W. J. Addison, Glasgow; Association of Registered Medical'Women. Secretary of, London; Dr. F. H. Alderson, London; Dr. R. J. Anderson, Newry; Antihumbug. B Berkshire; British Aynæcological Society, Secretary of, London; Mr. E. Berdoe, London; Mr. W. Bryce, Edinburgh; Mr. S. H. Berry, London; Dr. J. O. W. Barratt, London; Dr. L. A. Bidwell, London; Mr. J. P. Bush, Clifton; Mr. J. B. Blackett, London;
Mr. W. Basset, Newport, Mon.; Mr. F. B. J. Baldwin, Rotherham; Dr. B. Bramwell Edinburgh ; J. W. Batterham, M.B., St. Leonards; Messrs. Burroughs, Wellcome, and Co., London; Mr. A. S. Barling, Lancaster; Mr. H. S. Basden, Stanford-le-Hope. C Mr. B. Clarke, Bournemouth; Cymro; Mr. H. Caudwell, Woodstock: F. P. S. Cresswell,
M.B. Cardiff: Mr. F. H. Cooke, Birch ; C. A.; Dr. A. C. Coles, Bournemouth Mr. J.W. M.B., Cardiff: Mr. F. H. Cooke, Birch; C. A.; Dr. A.C. Coles, Bournemouth Mr. J. W. Clark, Cambridge; Civil Surgeon, not a General Practitioner. D C. W. Daniels, M.B., Georgetown; Mr. F. W. Dingle, Bath; Mr. A. R. Douglas, Portland; Sir Dyce
Duckworth, London; H. Distin, M.B., Enfleld; Dr. A. Duke, Cheltenham; Messrs. Duckworth, London; H. Distin, M.B., Enfeld ; Dr. A. Duke, Cheltenham; Messrs.
Dawbern and Ward, London; J. Duncan, M.B. Ashton-under-Lyne; Dr. A. T. Davies, Dawbarn and Ward, London; J. Duncan, M.B., Ashton-under-Lyne; Dr. A. T. Davies,
London ; Mr. E. Darke, London: W. Duncan, M.B., Aberdeen ; Dr. C. Dukes, Rugby Dr. o. C. Douglas, Glasgow; Dr. H. G. Dyer, Ringwood. E Mr. A. R. F. Evershed, Penzance. F Mr. W. T. Freeman, Reading; F. P.; Mr. T. E. Fliteroft, Bolton; W. S. Frew. M.B., Princetown; W. F. Farquharson, M.B., Carlisle. G Dr. E. Gwynn, London; Mr J. G. Gabe, Morriston; Mr. F. G. Gardner, Warwick ; Dr. F. W. Grant, Elgin ; Miss C. L
Gott, Paris : Mr. W. S. Granger. Weymouth ; Dr. G. I. Gulland, Edinburgh. H Dr. F. Gott, Paris ; Mr. W. S. Granger, Weymouth ; Dr. G. L. Gulland, Edinburgh. H Dr.
Hinds, Worthing; G. Halley, M.B., Dundee ; Mr. M. J. Haughton, London; Mr. B. Hartzhorne, London; Dr. L. Henry, Melbourne; Mr. A. Hunter, Port Said ; Dr. J. P. Henry, London: Mr. J. T. Hereford, Kingston-on-Thames ; Mr. F. H. Hudson, London I Iodoform. J W. D. Johns, M.B., Bournemouth; Dr. F. W. Jordan, Stockport; Dr. J. Johnston, Bolton; J. S. B.; J. H. K.; Dr. R. Jardine, Glasgow; Dr. R.J Jones, Woodford
Bridge; Dr. R. Jones, Blaenau-Festiniog. K G. E. Keith, M.B., London. I Mr. R. P. Bridge; Dr. R. Jones, Blaenau-Festiniog. K G. E. Keith, M.B., London. W Mr. R. P.
Iawson, Manchester; Mr. C. S. Loch, London; Dr. E. Leward, Zastron; Dr. J. F. Little London; Lint; W. Leask, M.B., Birkenhead; Mr. C. E. Lay, Peasenhail; Mr. C. E. Lister, London; Dr. W. T. Law, London; Mr. H. J. Lloyd, Barmouth. M A. McCulloch, M.B., Tarporley ; Mr. M. P. Macnaughton, London; Messrs. S. J.Moreland and Sons, Gloucester; Mr. R. MacGregor, Dumfries; Mr. V. Matthews, London; M.B.; Miss G. L Mallet, London; Dr. E. F. Moore, Letterkenny ; A. M. Martin, M.B., Newcastle-on-Tyne Mr. F. H. Madden, London; Member; Dr. R. F. McCraith, Liverpool : Mr. G. B. Mathieson, Doune; Mr. H. C. Martin, Wroughton. P Dr. J. Pringle, Manchester Messrs. Parke, Davis, and Co., London ; Dr. C. Porter, Stockport; Mr. T. Perkins, BradMr. A. Pain, London; J. C. Potter, M. B., Spennymoor; ; Dr. F. J. Poynton, London; Dr. A. M. Paterson, Liverpool ; Practitioner. Q Quo Fata Vocant. R Mr. J. D. Rhodes, Plumstead; Red Cross Society, Secretary of, London; Dr. W. F. Robertson, Edinburgh
Mr. D. Rockwood, London; G. A. Robinson, M.B., Holmwood ; Dr. W. R. Rice, Coventry Mr. D. Rockwood, London; ; G. A. Robinson, M.B., Holmwood; Dr. W. R. Rice, Coventry;
Dr. J. S. R. Russell, Lordon; R. M.; Mr. G. Rendle, London; Dr. A. W. Robson, BirmingDr. J. S. R. Russell, Lordon; R. M.; Mr. G. Rendle, London; Dr. A. W. Robson, Birmingham; Dr. J. M. Rhodes, Manchester; Ro;aliMedic ll and Chirurgical Society, Secretary of, London. S. W. A.; Mr. W. P. Stocks, Salford; Dr. W. H. Sturge, Florence - Dr
A. C. Sym, Edinburgh ; A. J. B. Squire, M.B., London; W. C. Sharpe, M.B., Darley Dale;

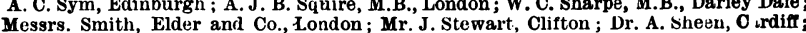
Dr. T. S. Short, Birmingham; Mr. P. S. Spokes, London; Dr. T. D. Savill, Lundon Surgeon-Major Ketired H.P. Dr. R. P Simpson, Weymouth. "School World," Editor of the, London. T Dr. H. Tilleg, London; Mr. G. Thomas, Prestatyn; Mr. S. Thistlethwaite. Ashton-on-Mersey; Dr. W. Thorburn, Manchester; Messrs. R. Tuck and Sons, London; Miss L. Thornton, Swansea ; Dr. J. C. Thresh, Chelmsford; Mr. W. T. Thomas, Liverpool; Dr. D. Thomson, London; T. P. W Dr. A. O. Ward, London; Mr. W. StC. Willeocks, London; Dr. F. P. Weaver, London: Mr. R. H. Wolstenholme, Salford; Mr. G. S. Walton, Sutton; Dr. S. R. Wells, London; Mr. L. K. G. Wilson, London; Miss Wilkinson, London. Y Mr. M. T. Yarr, London; Dr. P. A. Young, Edinburgh; etc.

\section{BOOKS, LW. KECEIVED.}

Kritische Betrachtungen uher Ernahrung, The Illustrated Annual of Microscops.
Stotfwechsel und Kissinger Kuren. Vou . London: Percy Lund, Humphries, and Co. Stoff wechhel und Wissinger Kuren. Voi .. London: Percy Lund, Humphries, and
Dr. R. Brasch. Wiesbaden. J. F. Berg- 1898 . $\operatorname{mann}_{1898 .}$; and 9 d. Glasgow: F. Bauermeister, Chirurgie des Voies Urinaires. Von Dr. E.
Chevalier. Paris : J. B. Bailliere et Pills. der praktischen und operativen Augen- Arbeiten aus dem Gesammtgebeit der $\begin{array}{lll}\text { heilkunde. Von Dr. H. Kuhnt. Wies- } & \text { Psychiatrie und Neuropathologie. Von } \\ \text { baden: J. F. Bergm inn; and Glasgow : F. } & \text { R. Kraftit-Ebing. } \\ \text { Heft III. Laipzig: J. }\end{array}$

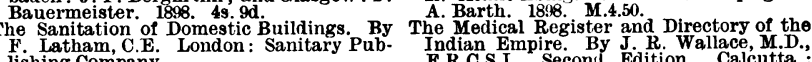

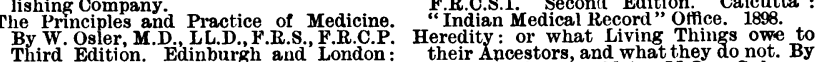
Third Edition. Edinburgh and London:
Young J. Pentland. 1898.
their Ancestors, and what they do not. By

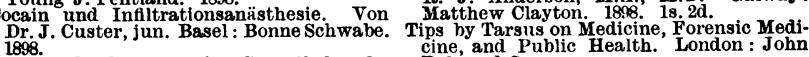
1898 .
Wei ist die Fürsorge filir Gemuthskranke Bale, and Ponblic Health. London: John
von Aerzten und Laien zu forden? An Atlas of Bacteriolog. By C. Slater,

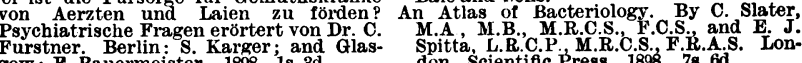
gow: P. Bauermeister. 1898. 1s. 3d.

\section{SCALE of CHaRges FOR ADVERTISEMENTB IN THE} BRITISH MEDICAL JOURNAT.

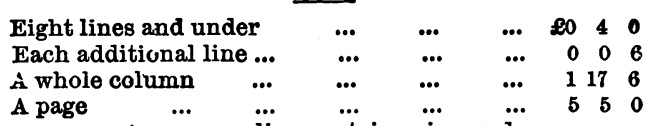

An average line contains six words.

Advertisements should be delivered, addressed to the Manager, at the Office, not later than noon on the Wednesday preceding publication; and if not paid for at the time, should be accompanied by a reference.

Post-Office Orders should be made payable to the British Medical Asso ciation at the General Post-Office, London. Small amounts mas be paid in postage-stamps.

N.B.-It is against the rules of the Post Office to receive latters at Postee Restantes addressed either in initials or numbers. 